\title{
Clinical Characteristics, Etiology and Phylogenetic Distribution of Bacteremia in Patients with Malignancies in Basrah Province
}

\author{
Lamyaa Abdul-Hussein Abdul-Ridha1, Munaff JawdatAbd Al- \\ Abbas $^{2}$
}

\author{
${ }^{1,2}$ Dept. of Biology, College of Science, University of Basrah, Basrah, Iraq
}

\begin{abstract}
This is the first study in Basrah province/Iraq to detect the geographical distribution of adult oncology patients with bacteremia and the bacterial etiology. From 176 patients' samples, the highest incidence of cancer cases was recorded in central $62(35.22 \%)$ followed by western $45(25.56 \%)$, northern 34 (19.31\%), southern 24 $(13.63 \%)$ and eastern $11(6.25 \%)$ regions. The majority of cancer with bacteremic episodes (64) were located in the central $23(35.93 \%)$, western $16(25 \%)$ and southern $13(20.31 \%)$ regions, while they were less likely to occur in the northern $7(10.93 \%)$ and eastern $5(7.81 \%)$ regions. Some clinical characteristics, including age (30-60 year), leukemia $(64.06 \%)$, healthcare exposure $(73.43 \%)$, neutropenia $(71.87 \%)$, non-antibiotic administration $(81.25 \%)$ and fever $(100 \%)$ were associated with bacteremic episodes. Sixty-three $(98.43 \%)$ of these episodes were caused by Gram-positive pathogens, especially 48 (75\%) Bacillus spp., these were 21 B. licheniformis, 19 B. cereus, 3 B. subtillus, 3 B. sonorensis, 1 B. aeruius and 1 B. toyonensis. On the other hand, 3 Staphylococcus epidermidis, 1 isolate of S. warneri, Lysinibacillus sphaericus, Lysinibacillus xylanilyticus, Enterobacter cancerogenous and 9 other of Gram-positive bacteria (unidentified). Exclusively, this is the first study isolated Gr-ve Enterobacter cancerogenous from cancer patients with bacteremia. Three isolates Bacillus licheniformis "IRQBAS18", Bacillus licheniformis "IRQBAS19" and Bacillus licheniformis "IRQBAS20" were reported as new global bacterial strains. RAPD analysis showed four patients from different regions, each two (9.5\% for each) had the same strain of Bacillus licheniformis and other four (19.04\%) patients from different regions had closely related strains of Bacillus licheniformis, these results confirm that the bacteremic infections were coming from the same source.
\end{abstract}

Keywords: Bacteremia, Bacillus, licheniformis, cancer, RAPD

\section{Introduction}

Cancer is a growing problem over the world, the etiology of many types of cancer is still ambiguous and the role of specific risk factors in certain cancers is unsolved with across the world, Iraq as whole and the southern region including Basrah, has been exposed to tremendous environmental damage as a result of wars, economic siege and lack of resources to protect or reinstate secure environment, as a consequence, the health condition of the population was under high risk of different diseases such as cancer (Essa et al., 2007). The latest statistics presented by Iraqi Cancer Board / Cancer Registry Center for the year 2011 recorded 1420 cancer cases in Basrah province outperforming the rest of Iraq's provinces cases (CSO, 2014).
Blood stream infection (BSI) remains a serious cause of grievous complications in patients receiving anticancer chemotherapy, by leading to delay and reduce dosages of chemotherapeutics, by causing longer hospitalizations, it participates in suboptimal treatment, higher mortality rate and incremented health care costs to cancer patients (Montassier et al., 2013). BSIs include bacteremia indicating the presence of bacteria in the blood (Gopal Katherason et al., 2010). The most common risk factors reported for bacteremia are: younger age at onset of bacteremia, absolute neutrophil count (ANC) 500 cells $/ \mu 1$, bone marrow status, intravascular catheters, high temperature and more immunosuppressive anticancer regimens (Al-Mulla et al., 2014).

This article is published under the terms of the Creative Commons Attribution License 4.0 Author(s) retain the copyright of this article. Publication rights with Alkhaer Publications.

Published at: http://www.ijsciences.com/pub/issue/2016-11/

DOI: 10.18483/ijSci.1150; Online ISSN: 2305-3925; Print ISSN: 2410-4477 
Patients with malignancies have been characterized by a variable spectrum of pathogens as a cause of BSIs in the last three decades, at the star of the $80 \mathrm{~s}$, Gram-negative bacteria were responsible for approximately two- thirds of the infections in most clinical centers, at the end of the 80 s the trend was differed, Gram-negative pathogens accounted for one-third, in $90 \mathrm{~s}$ and in the $21^{\text {st }}$ century, Grampositive bacteria have dominated. (Åttman et al., 2015). Especially, Coagulase-negative Staphylococci (CoNS), Staphylococcus aureus, viridans group Streptococci, $\quad \beta$-hemolytic $\quad$ Streptococci, Streptococcus pneumoniae and various organisms that colonize the human skin, such as Bacillus species and Corynebacterium species (Wisplinghoff et al., 2003; Rolston et al., 2006). For bacterial identification, $16 S \mathrm{rDNA}$ sequencing is important in the case of bacteria with uncommon phenotypic profiles, rare bacteria, slow growing bacteria, uncultivable bacteria, culture-negative infections and new bacterial strains (Woo et al., 2008; Abd Al-Abbas and Chmagh 2014). Molecular characterization techniques are now widely used for ecological and epidemiological analyses of a wide range of bacterial species such as Randomly amplified polymorphic DNA (RAPD) which is a PCR-based technique, using arbitrary primers to detect changes in the DNA sequence at sites in the genome (Maiti et al., 2009). This technique is fast and inexpensive, can detect DNA variations even at a single-base level, hence, it has become a commonly used technique for exploring intraspecies and interspecies diversity, thus, detecting the epidemiology of bacterial species (El-Hamshary et al., 2012).

The aim of this study was to determine the phylogenetic relatedness of bacteremia among cancer patients in Basrah regions at the strain level and their frequencies according to some clinical characteristics.

\section{Materials and Methods \\ Sample collection}

One-hundred and seventy-six samples were enrolled from patients with malignancies received various types of chemotherapy. There were two major types of malignancy: 1- hematological malignancy (102 samples) included leukemia (69) and lymphoma (33). 2- solid tumors (74) from breast, lung, osteosarcoma, prostate, ovary, gastrointestinal (pancreatic, stomach, colorectal and liver), bladder, uterus, kidney and cup cancers. The patients attended and /or admitted to The Center of Oncology and Hematology/Al-Saddar Educational Hospital in Basrah province from December 2013 to February 2014. Samples were gained by informed agreement of patients, with the permission of the center and Al-Basrah health directorate. All samples were withdrawn under aseptic conditions using EDTA tube and transported immediately to the Laboratory. All blood specimens were aseptically added to the sterilized tubes containing brain heart infusion broth (1:5 dilutions) and incubated aerobically at $37^{\circ} \mathrm{C}$ for $24 \mathrm{~h}$ then subcultured on blood agar plates (Parikh et al., 2012). All isolates were Gram stained and undergone to next assays.

\section{Genomic DNA extraction}

Five ml of Brain Heart Infusion broth (BHIB) was inoculated with one tested bacterial colony and incubated at $37{ }^{\circ} \mathrm{C}$ for $18 \mathrm{~h}$. The grown bacteria were washed three times, in normal saline and centrifuged for 5 minutes at $13,000 \quad$ X $\mathrm{g}$ (Japoni et al., 2004). Pure genomic DNA was extracted by ExiPrep ${ }^{\mathrm{TM}} 16$ plus Genomic Bacterial DNA kit (Bioneer, Korea) using ExiPrep ${ }^{\mathrm{TM}} 16$ plus automatic nucleic acid extraction instrument (Bioneer, Korea). DNA samples were electrophoresed in $0.8 \%$ agarose gel containing $1 \%$ ethidium bromide at $60 \mathrm{~V}$ for $30 \mathrm{~min}$.

\section{$16 S \mathrm{rDNA}$ gene amplification}

A molecular identification of the bacteria was performed by amplifying the $16 \mathrm{~S}$ rDNA using the universal oligonucleotide primers $27 \mathrm{~F}$ (5'AGAGTTTGATCC TGGCTCAG-3') and 1492R (5'- GGTTACCTTGTTACGACTT-3') according to Miyoshi et al. (2005). Gene amplification was performed in a final volume of $50 \mu 1$ of reaction mixtures contained $1.5 \mu \mathrm{l}$ DNA template, $1.5 \mu \mathrm{l}$ forward primer $(10 \mathrm{pmol}), 1.5 \mu \mathrm{l}$ reverse primer (10pmol), $11 \mu \mathrm{l}$ AccuPower ${ }^{\circledR}$ PCR PreMix (Bioneer, Korea) and $34.5 \mu \mathrm{l}$ nuclease-free water. The amplification conditions for PCR were as follows: initial denaturation at $92^{\circ} \mathrm{C}$ for $2 \mathrm{~min}$ followed by 30 cycles each consisted of denaturation at $94^{\circ} \mathrm{C}$ for $30 \mathrm{~s}$, annealing at $51.8^{\circ} \mathrm{C}$ for $45 \mathrm{~s}$ and extension at $72^{\circ} \mathrm{C}$ for $1 \mathrm{~min}$ and $30 \mathrm{~s}$, with a final extension at $72^{\circ} \mathrm{C}$ for 5 min by MyGenie ${ }^{T M}$ 96/384 thermal cycler (Bioneer, Korea). PCR product was separated on a $2 \%$ agarose gel with $1 \%$ ethidium bromide, the $16 S \mathrm{rDNA}$ bands (1500bp) were visualized under UV trans-illuminator and photographed by LG camera.

\section{S rDNA gene sequences}

Polyethylene Glycol (PEG) Precipitation was used to clean up PCR products prior to sequence. Briefly, 60 $\mu \mathrm{l}$ of $30 \%$ polyethylene glycol 6000 (Applied Biosystem, USA) was added to $30 \mu$ of PCR product (16S rDNA gene) and mixed by vortex (Fisher scientific, USA) then incubated at $4^{\circ} \mathrm{C}$ overnight after centrifugation (Eppendorf, Germany) at $1200 \mathrm{rpm}$ for $20 \mathrm{~min}$, the pelleted DNA was mixed with $0.5 \mathrm{ml}$ of $70 \%$ chilled ethanol and centrifuged (this step repeated twice). The recentrifuged product was dried 
in an eppendorf concentrator (Eppendorf, Germany) for $30 \mathrm{~min}$. The pellet was dissolved in $30 \mu \mathrm{l}$ of nuclease free water and left overnight at $4{ }^{\circ} \mathrm{C}$, the purified PCR product was running out onto $2 \%$ agarose gel containing $1 \%$ ethidium bromide (Abd Al-Abbas and Chmagh, 2014). Purified PCR products were sequenced at MACROGEN Co. /Korea.

\section{Identification of bacterial species}

16S rDNA gene sequence was recorrected then analyzed using Basic Local Alignment Search Tool 'BLAST' to search for homologous sequences in the National Center for Biotechnology Information database (NCBI) http://www.blast.ncbi.nlm.nih.gov.

\section{Detection of identical bacterial strains using Random Amplified Polymorphic DNA (RAPD) - PCR}

RAPD - PCR was carried out according to Ronimus et al. (1997) for Bacillus lechniformis using five primers each comprised of 10 nucleotides (Table 1). Reaction mixtures of PCR amplification for each primer was prepared in a volume of $20 \mu \mathrm{l}$ consisted of $2.5 \mu \mathrm{l}$ of DNA templates, $1.5 \mu \mathrm{l}$ of primer (30pmol), $5 \mu \mathrm{l}$ of AccuPower ${ }^{\circledR}$ PCR PreMix (Bioneer, Korea) and $11 \mu 1$ of nuclease free water. PCR amplification was done using the following conditions: initial denaturation at $94^{\circ} \mathrm{C}$ for $3 \mathrm{~min}$ and $45 \mathrm{~s}, 35$ cycles include denaturation at $94^{\circ} \mathrm{C}$ for $15 \mathrm{~s}$, annealing at 36 ${ }^{\circ} \mathrm{C}$ for $15 \mathrm{~s}$ and extension at $72^{\circ} \mathrm{C}$ for 2 min followed by a final extension at $72^{\circ} \mathrm{C}$ for $4 \mathrm{~min}$ by Veriti ${ }^{\circledR}$ thermal cycler (Applied Biosystem, USA). The RAPD patterns were detected by $2 \%$ agarose gel containing $1 \%$ ethidium bromide and photographed by LG camera. The amplification reactions were performed five times for each isolate/primer combination.

\section{Table 1: primers used in RAPD-PCR}

\begin{tabular}{|c|c|}
\hline Primer & Primer Sequence $5^{\prime}-3^{\prime}$ \\
\hline 1 & TGCGGGTCCT \\
\hline 2 & CACAGCTGCC \\
\hline 3 & GGACGACAAG \\
\hline 4 & GGACAACGAG \\
\hline 5 & CTCTGCGCGT \\
\hline
\end{tabular}

\section{RAPD -PCR data analysis}

Gel image analysis was performed using BioNumerics software v 7.6 (Applied Maths, Belgium). The digital images were inserted into the software and the bands were marked after standardization using a 100bp DNA ladder. The similarity was calculated using the number of different bands coefficient with an optimization of 1 $\%$, a tolerance of $1 \%$. The Unweighted Pair Group Method with Arithmetic mean (UPGMA) was used for clustering. In addition to the dendrograms obtained for each primer separately, a combined analysis was performed using the average from experiments. Then, the similarity matrices from each experiment was calculated first and from these matrices a combined matrix is calculated by average in the values, giving each independent analysis the same equal weight (Towner et al., 2008).

\section{Statistical analyses}

One sample T- test, one-way ANOVA were performed to evaluate associations among the categorical data using IBM SPSS statistics 19 software, and $P \leq 0.05$ were considered statistically significant.

\section{Results \\ Geographical distribution of bacteremic and non- bacteremic cancer patients}

The distribution of 176 cancer cases in different geographical areas in Basrah province is illustrated in Table (2). The highest incidence was recorded in central regions $62(35.22 \%)$ then in western (AlZubair district inclusive of Safwan and Um-Qasr) 45 (25.56\%), Northern (Al-Hartha, Al Qurna and Al Medina) 34 (19.31\%), southern (Abu Al-Khaseeb and Fao districts) 24 (13.63\%) and eastern (Shatt AlArab district) $11(6.25 \%)$ regions, all at $P \leq 0.05$.

The majority of 64 bacteremic episodes was located in central, western and southern regions while they were less likely in eastern and northern regions (Table 3). The bacteremic episodes in central regions $(35.93 \%)$ appeared that $7(41.17 \%)$ of patients had a history of hospitalization, as for western regions, from $16(25 \%)$ cases, $1(5.88 \%)$ of patients had a history of hospitalization, in southern regions 13 $(20.31 \%), 4(23.52 \%)$ of patients had a history of hospitalization, in Northern area 7 (10.93\%), 2 (11.76) of patients had a history of hospitalization, in eastern regions $5(7.81 \%), 3(17.64 \%)$ of patients had a history of hospitalization. All those comparisons have a significant difference at $P \leq 0.05$, but between hospitalized and healthcare patients there was no significance in central and western regions. Generally, bacteremic episodes were more frequented in healthcare center patients' 47 (37.43\%) compared

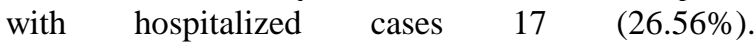


Clinical Characteristics, Etiology and Phylogenetic Distribution of Bacteremia in Patients with Malignancies in Basrah Province

Table 2: Geographical distribution of cancer cases in Basrah province

\begin{tabular}{|l|c|}
\hline \multicolumn{1}{|c|}{ Regions } & Total $\mathrm{n}(\boldsymbol{\%})$ \\
\hline Western (Al-Zubair district, Safwan and Um-Qasr) & $45(25.56)^{\mathrm{b}}$ \\
\hline Southern (Abu Al-Khaseeb and Fao districts) & $24(13.63)^{\mathrm{d}}$ \\
\hline Central & $62(35.22)^{\mathrm{a}}$ \\
\hline Northern (Al-Hartha, Al Qurna and Al Medina) & $34(19.31)^{\mathrm{c}}$ \\
\hline Eastern (Shatt Al-Arab district) & $11(6.25)$ \\
\hline Total & $176(100)$ \\
\hline
\end{tabular}

The mean difference is significant at $P \leq 0.05$.

$\mathrm{a}, \mathrm{b}, \mathrm{c}, \mathrm{d}$ differences from high to low

Table 3: Geographical distribution of cancer patients with bacteremia in Basrah province

\begin{tabular}{|c|c|c|c|}
\hline Regions & $\begin{array}{l}\text { Hospitalized } \\
\text { patients'n (\%) }\end{array}$ & $\begin{array}{c}\text { Healthcare patients' } \\
\mathrm{n}(\%)\end{array}$ & Total n (\%) \\
\hline $\begin{array}{l}\text { Western (Al-Zubair district, Safwan and } \\
\text { Um-Qasr) }\end{array}$ & $1(5.88)^{d}$ & $15(31.91)^{\mathrm{a}}$ & $16(25)^{b}$ \\
\hline $\begin{array}{l}\text { Southern (Abu Al-Khaseeb and Fao } \\
\text { districts) }\end{array}$ & $4(23.52)^{b}$ & $9(19.14)^{b}$ & $13(20.31)^{c}$ \\
\hline Central & $7(41.17)^{\mathrm{a}}$ & $16(34.04)^{\mathrm{a}}$ & $23(35.93)^{a}$ \\
\hline $\begin{array}{l}\text { Northern (Al-Hartha, Al Qurna and Al } \\
\text { Medina) }\end{array}$ & $2(11.76)^{b}$ & $5(10.63)^{c}$ & $7(10.93 \%)^{d}$ \\
\hline Eastern (Shatt Al-Arab district) & $3(17.64)^{b, c}$ & $2(4.25)^{d}$ & $5(7.81)$ \\
\hline Total & $17(26.56)$ & $47(73.43)$ & $64(100)$ \\
\hline
\end{tabular}

The mean difference is significant at $P \leq 0.05$.

a, b, c, d differences from high to low.

Clinical characteristics of bacteremic and nonbacteremic cancer patients

Sixty-four $(36.3 \%)$ bacteremic episodes in 176 cancer patients were detected, statistically significant difference for some factors between bacteremic and non bacteremic cancer patients was observed at $P \leq$ 0.05 (Table 4). The age group 30-60 years was more frequent among bacteremic $38(59.25 \%)$ and non bacteremic 68 (60.71) cancer patients than other age groups. The bacteremic episodes among leukemic patients was observed to be significantly higher 41 $(64.06 \%)$ followed by solid tumors 15 (23.43\%) while the majority of non bacteremic cancer patients was for solid tumor $61(54.46 \%)$. The correlation between neutropenia and bacteremia was positive 46 $(71.87 \%)$. The episodes of bacteremia were significantly higher among healthcare center patients $47(73.43 \%)$, similarly, the number of bacteremic cancer patients who did not have a history of antibiotic intake $52(81.25 \%)$ were higher than those who had a history of antibiotic intake. There were no significant differences between bacteremic and non bacteremic cancer patients associated with age, sex, healthcare exposure, surgery, neutropenia and antibiotic administration.

\section{Identification of bacterial species}

16S rDNA Gene was amplified in all 64 bacteremic samples analyzed (Figure 1). Only fifty-five isolates were successfully sequenced, aligned with BLAST and bacteria were identified to species level (Table 5). Four genera and eleven species have been identified, Gram-positive bacteria were more common 63 (98.43\%) than Gram-negative bacteria 1 $(1.56 \%)$, the most common Gram-positive pathogen was $21(32.81 \%)$ Bacillus licheniformis followed by 19 (29.68\%) Bacillus cereus, 3 (4.68\%) Bacillus subtilis, 3 (4.68) Bacillus sonorensis and 3 (4.68\%) Staphylococcus epidermidis. Moreover, 1 (1.56\%) isolate of Bacillus aerius, Bacillus toyonensis, $S$. warneri, Lysinibacillus sphaericus, Lysinibacillus xylanilyticus and other 9 Gram-positive bacteria (unidentified) were also isolated. The Gram-negative pathogen was only found in $1(1.56 \%)$ which identified as Enterobacter cancerogenous. There was a significant correlation between the frequency of bacterial species isolated from the blood of cancer patients at $P \leq 0.05$, furthermore, the bacteremic episodes was significantly higher in leukemia patients with predominant of B. cereus 14 (21.87\%) compared with lymphoma 
Table 4: Clinical characteristics of bacteremic and non-bacteremic cancer patients

\begin{tabular}{|c|c|c|c|}
\hline \multicolumn{2}{|c|}{ Characteristics } & $\begin{array}{c}\text { Bacteremia patients' } \\
(\%)\end{array}$ & $\begin{array}{c}\text { Non-bacteremia patients' } \\
\text { n (\%) }\end{array}$ \\
\hline \multirow{3}{*}{ Age (years) } & $<30$ & $11(17.18)^{\mathrm{c}}$ & $20(17.85)$ \\
\cline { 2 - 4 } & $30-60$ & $38(59.25)^{\mathrm{a}}$ & $68(60.71)$ \\
\cline { 2 - 4 } & $>60$ & $15(23.56)^{\mathrm{b}}$ & $24(21.42)$ \\
\hline \multirow{2}{*}{ Sex } & Male & $33(51.56)$ & $51(45.53)$ \\
\cline { 2 - 4 } & Female & $31(48.43)$ & $61(54.46)$ \\
\hline \multirow{3}{*}{ Malignancy } & Leukemia & $41(64.06)^{\mathrm{a}}$ & $28(25)^{\mathrm{b}}$ \\
\hline & Lymphoma & $8(12.5)^{\mathrm{c}}$ & $25(22.32)$ \\
\hline & Solid tumor & $15(23.43)^{\mathrm{b}}$ & $61(54.46)$ \\
\hline \multicolumn{2}{|c|}{ Healtcare center patients } & $47(73.43)^{\mathrm{a}}$ & $96(85.71)$ \\
\hline \multicolumn{2}{|c|}{ Surgery } & $25(39.06)$ & $20(17.85)$ \\
\hline \multicolumn{2}{|c|}{ Neutropenia } & $46(71.87)^{\mathrm{a}}$ & $44(39.28)$ \\
\hline \multicolumn{2}{|c|}{ Non-antibiotic administration } & $52(81.25)^{\mathrm{a}}$ & $97(86.6)$ \\
\hline \multicolumn{2}{|c|}{ Fever } & $64(100)$ & $109(97.32)$ \\
\hline \multicolumn{2}{|c|}{ Total number } & $64(36.3)^{\mathrm{b}}$ & $112(63.6)^{\mathrm{a}}$ \\
\hline
\end{tabular}

The mean difference is significant at $P \leq 0.05$.

a, b, c differences from high to low.

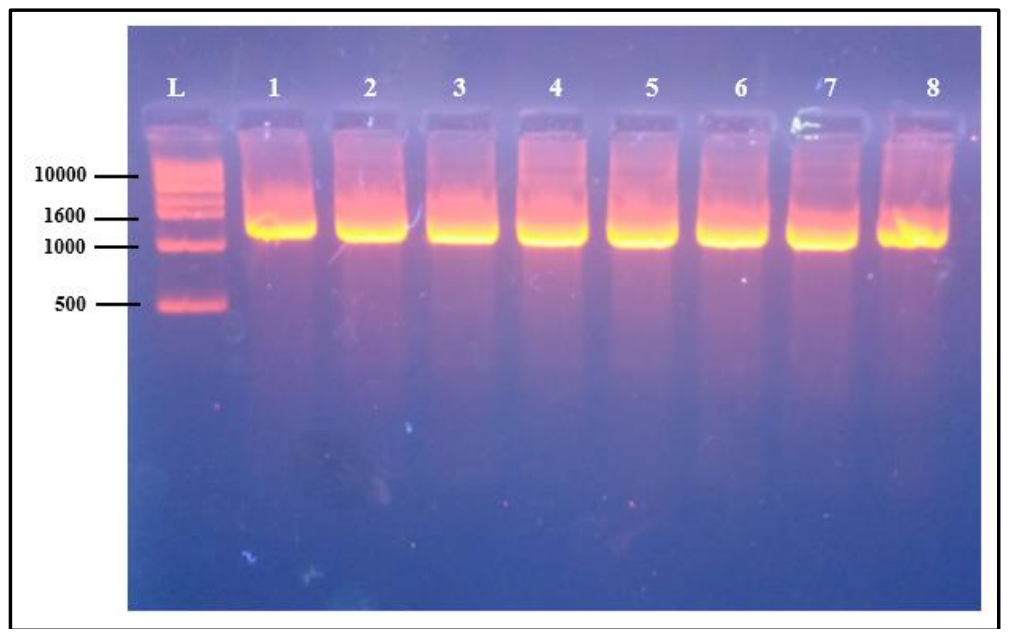

Figure 1: Amplification of $16 S$ rDNA gene form bacterial isolates showed by $2 \%$ agarose gel containing ethidium bromide: Lane L: 1kb molecular weight DNA ladder, Lane 1-8: $16 S$ rDNA gene bands of bacterial isolates (1500bp).

and solid tumor in which B. licheniformis was the most common species 3 (4.68\%) and $10(15.62 \%)$ respectively. 
Clinical Characteristics, Etiology and Phylogenetic Distribution of Bacteremia in Patients with Malignancies in Basrah Province

Table 5: Bacterial species of bacteremia episodes in leukemia, lymphoma and solid tumor cases

\begin{tabular}{|c|c|c|c|c|}
\hline \multirow{2}{*}{ Bacterial species } & \multirow{2}{*}{ Total n (\%) } & \multicolumn{3}{|c|}{ Malignancy (\%) } \\
\hline & & Leukemia & Lymphoma & Solid tumor \\
\hline Bacillus licheniformis & $21(32.81)^{\mathrm{a}}$ & $8(12.5)^{b}$ & $3(4.68)^{a}$ & $10(15.62)^{\mathrm{a}}$ \\
\hline Bacillus cereus & $19(29.68)^{b}$ & $14(21.87)^{\mathrm{a}}$ & $2(3.12)^{a}$ & $3(4.68)^{b}$ \\
\hline Bacillus subtilis & $3(4.68)^{c}$ & $2(3.12)^{c}$ & $1(1.56)^{b}$ & - \\
\hline Bacillus sonorensis & $3(4.68)^{c}$ & $1(1.56)^{d}$ & - & $2(3.12)^{b}$ \\
\hline Bacillus aeurius & $1(1.56)^{c}$ & $1(1.56)^{d}$ & - & - \\
\hline Bacillus toyonensis & $1(1.56)^{c}$ & $1(1.56)^{d}$ & - & - \\
\hline Staphylococcus epidermidis & $3(4.68)^{c}$ & $3(4.68)^{c}$ & - & - \\
\hline Staphylococcus warneri & $1(1.56)^{c}$ & $1(1.56)^{d}$ & - & - \\
\hline Lysinibacillus sphaericus & $1(1.56)^{\mathrm{c}}$ & $1(1.56)^{\mathrm{d}}$ & - & - \\
\hline Lysinibacillus xylanilyticus & $1(1.56)^{c}$ & $1(1.56)^{d}$ & - & - \\
\hline Enterobacter cancerogenus & $1(1.56)^{c}$ & $1(1.56)^{d}$ & - & - \\
\hline Gram positive bacteria & $9(14.06)$ & $7(10.93)$ & $2(3.12)$ & - \\
\hline Total number & $64(100)$ & $41(64.06)^{\mathrm{a}}$ & $8(12.5)^{c}$ & $15(23.43)^{b}$ \\
\hline
\end{tabular}

The mean difference is significant at $P \leq 0.05$.

a, b, c, d differences from high to low

Identification of new bacterial strains

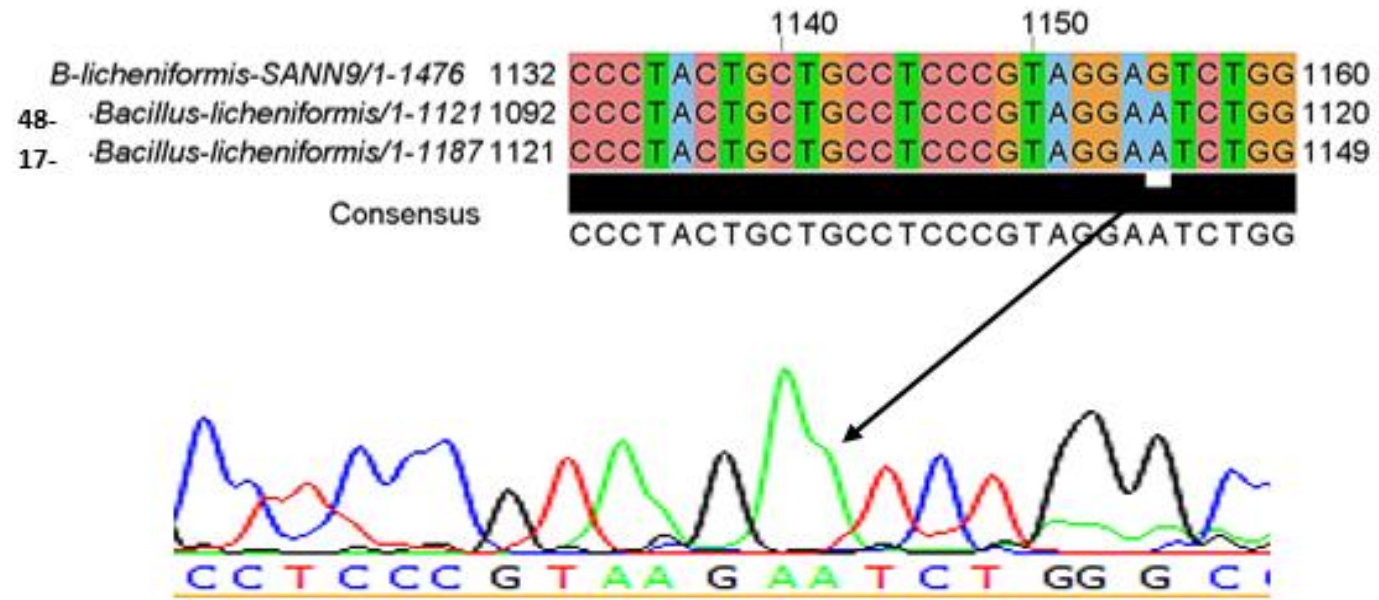

Bacillus licheniformis strain IRQBAS 18 and IRQBAS19

Figure 2: Comparison of $16 \mathrm{~S} r \mathrm{rNA}$ nucleotide sequences to isolates No. 17 and 48 with their type strain SANN9 showing the transition point mutation (A instead of $G$ ) at $1155 \mathrm{bp}$.

Three bacterial isolates were identified as global new strains which vary from their type strains in some nucleotide positions. These new bacterial isolates were recorded in the National Center for Biotechnology Information (NCBI) by European Nucleotide Archive (ENA) and GenBank for DNA sequences. First isolate No. 17 Bacillus licheniformis strain IRQBAS18 “LN871449”'and the second No. 48 Bacillus licheniformis strain IRQBAS19
"LN871450" were closely related $(99 \%)$ to Bacillus licheniformis strain SANN9 but with a transition point mutation (A instead of $G$ ) at $1155 \mathrm{bp}$ for both strains (Figure 2). The third bacterial isolate No.15 Bacillus licheniformis strain IRQBAS20 "LN871451" was closely related (99\%) to Bacillus licheniformis strain SANN7 with a transversion point mutation (C instead of A) at 1043bp (Figure 3). 


\section{0

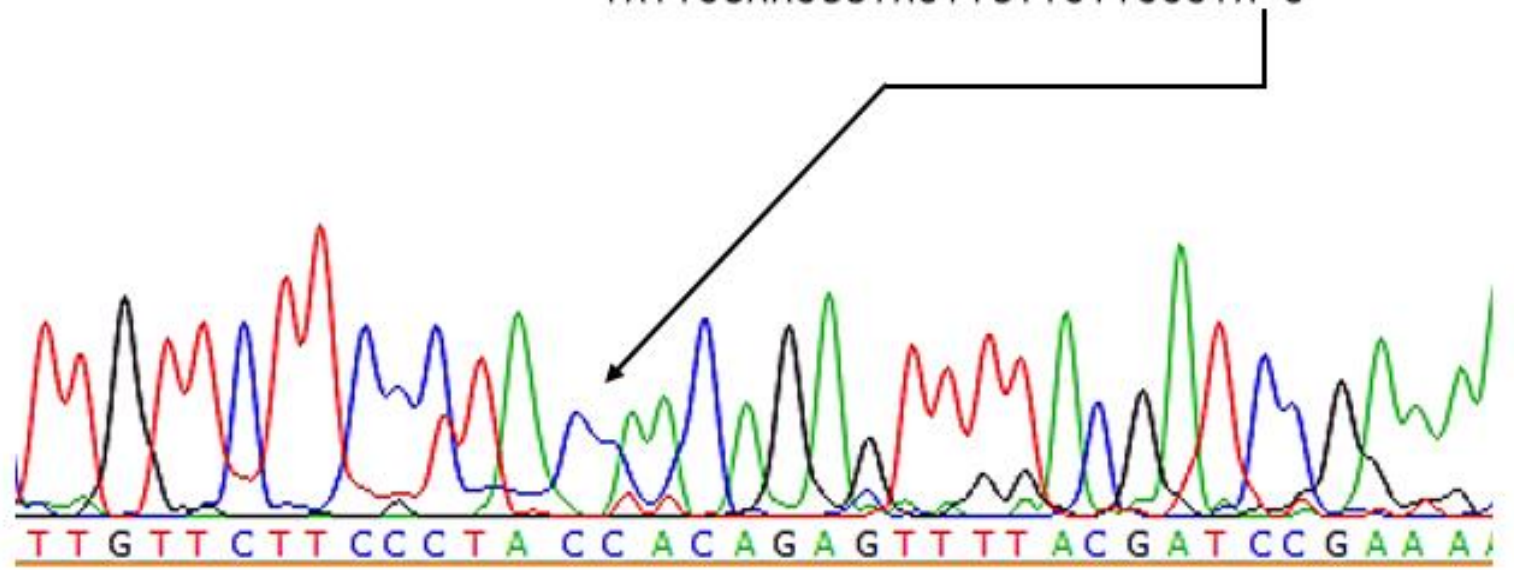

\section{Bacillus licheniformis strain IRQBAS20}

Figure 3: Comparison of $16 \mathrm{~S}$ rDNA nucleotide sequences to isolate No. 15 and its type strain SANN7 showing the transversion point mutation ( $C$ instead of $A)$ at $1043 \mathrm{bp}$.

\section{Detection of identical Bacillus licheniformis strains using Random Amplified Polymorphic DNA (RAPD) - PCR}

The RAPD technique was used for Bacillus licheniformis to generate strain - specific profiles for the tracing of those species among cancer patients. According to the dendrogram (Figure 4) Bacillus licheniformis was divided into five clades, four of 21 patients had identical strains. But, No. 1 from Abu Al-Khaseeb and No. 16 from Al-Hartha within clade 1 had the same strain of Bacillus licheniformis and No. 136 from Nathran and 161 from Al-Ddir within clade 4 had the other same strain of Bacillus licheniformis. However, the closely related strains were appeared in clade 1 which contained strain 18, 48 and 100 with $\geq 95.6 \%$ similarity (Table 6 ), clade 2 contained strains $1,11,16,17,63,37$ with $\geq 95.9 \%$ similarity and clade 3 contained strains 13, 15, 74, $77,78,112$ and 123 with $\geq 94.4 \%$ similarity. Clade 5 contained strains 10 and 12 with $\geq 90.8 \%$ similarity which were considered to be relative.

\section{Discussion}

The highest incidence of cancer cases was in central regions followed by western, northern, southern and eastern regions (Table1). Similarly, Hussain (2015) studied cancer in Basrah during 2010-2012 and reported the highest incidence of cancer cases was in the center while the lowest incidence was in southern and eastern regions, but the cases were also higher in northern and western regions. In the present study, this graduation in cases according to regions were identical (in most regions) to that cases of bacterial infection disease, which may be due to number and their economic capacity of populations to diagnosis then registration those cases in the healthy center (Table 2). $73.43 \%$ of cancer patients with bacteremia had a history of healthcare exposure and $26.56 \%$ of patients had a history of hospitalization suggesting that bacteremia is a healthcare associated rather than hospital acquired. Bacteremia has been traditionally classified as either community acquired (CA) or hospital acquired (HA), however, a third category Healthcare-associated BSI (HCA) community onset has been recognized and identified by recent hospital admission or exposure to a significant medical care in a community or outpatient setting (Lenz et al., 2012). Community-onset bacteremia were categorized as being healthcare associated if one or more of the subsequent criteria were present: outpatient treatment, hemodialysis, intravenous chemotherapy during the past 30 days, hospitalization for at least 2 days during the past year, home intravenous therapy, wound care during the past 30 days or residence in a long-term care facility 

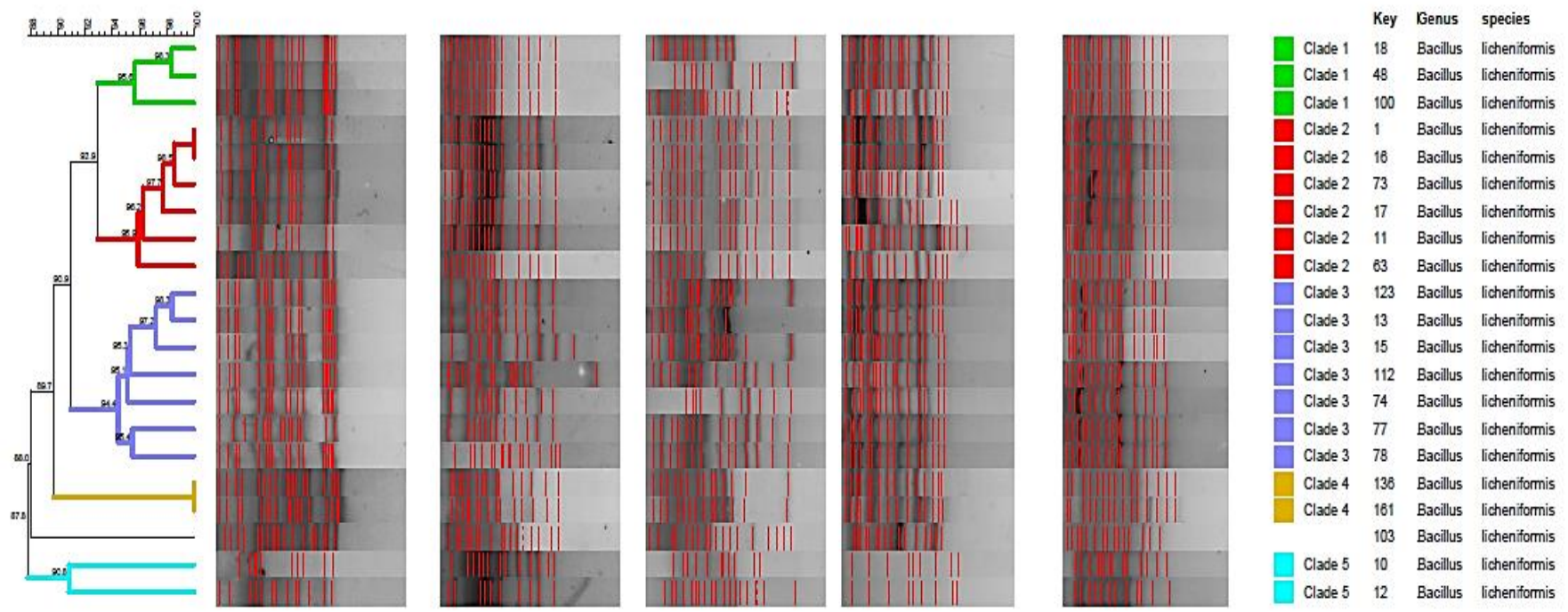

Figure 4: Dendrogram determined by RAPD-PCR fingerprints patterns of Bacillus licheniformis isolates recovered from the blood of cancer patients. The scale at the top of the figure shows the percentage similarity. The actual RAPD-PCR fingerprints were given on the right of the dendrogram and the subsequent columns refer to data concerning the isolates.

Table 6: Similarity matrix between each isolate of Bacillus licheniformis from the blood of cancer patients

\begin{tabular}{|c|c|c|c|c|c|c|c|c|c|c|c|c|c|c|c|c|c|c|c|c|c|}
\hline $\begin{array}{c}\text { Strai } \\
\mathbf{n}\end{array}$ & 18 & 48 & 100 & 1 & 16 & 73 & 17 & 11 & 63 & 123 & 13 & 15 & 112 & 74 & 77 & 78 & 136 & 161 & 103 & 10 & 12 \\
\hline 18 & 100 & & & & & & & & & & & & & & & & & & & & \\
\hline 48 & $983 \mathrm{~b}$ & 100 & & & & & & & & & & & & & & & & & & & \\
\hline 100 & $959 \mathrm{bb}$ & \begin{tabular}{|l|l|l}
95.4 \\
\end{tabular} & 100 & & & & & & & & & & & & & & & & & & \\
\hline 1 & 92.7 & \begin{tabular}{|l|l}
93.0 \\
\end{tabular} & 92.8 & 100 & & & & & & & & & & & & & & & & & \\
\hline 16 & 92.7 & \begin{tabular}{|l|l|}
92.6 \\
\end{tabular} & 92.8 & $100 \mathrm{a}$ & 100 & & & & & & & & & & & & & & & & \\
\hline 73 & \begin{tabular}{|l|}
94.1 \\
\end{tabular} & \begin{tabular}{|l|}
93.6 \\
\end{tabular} & 92.6 & $98.5 \mathrm{~b}$ & $98.5 \mathrm{~b}$ & 100 & & & & & & & & & & & & & & & \\
\hline 17 & 92.6 & \begin{tabular}{|l|l}
92.5 \\
\end{tabular} & 91.9 & $97.9 \mathrm{~b}$ & $97.9 \mathrm{~b}$ & 9736 & 100 & & & & & & & & & & & & & & \\
\hline 11 & 92.6 & \begin{tabular}{|l|}
91.8 \\
\end{tabular} & 90.9 & $95.7 \mathrm{~b}$ & 96.1b & $96.5 \mathrm{~b}$ & $96.6 \mathrm{~b}$ & 100 & & & & & & & & & & & & & \\
\hline 63 & 93.7 & \begin{tabular}{|l|l}
93.9 \\
\end{tabular} & $94.8 \mathrm{~b}$ & $96.3 \mathrm{~b}$ & $96.3 \mathrm{~b}$ & $96.5 \mathrm{~b}$ & $95.5 \mathrm{~b}$ & $94.6 \mathrm{~b}$ & 100 & & & & & & & & & & & & \\
\hline 123 & 92.5 & \begin{tabular}{|l|}
91.0 \\
\end{tabular} & 92.2 & $\begin{array}{l}92.0 \\
\end{array}$ & 91.8 & 90.0 & \begin{tabular}{|l|}
89.7 \\
\end{tabular} & 88.1 & 91.2 & 100 & & & & & & & & & & & \\
\hline 13 & 93.6 & \begin{tabular}{|l|}
92.0 \\
\end{tabular} & 91.5 & $\begin{array}{l}90.0 \\
\end{array}$ & 90.3 & 89.0 & 88.5 & 87.0 & 89.4 & 9836 & 100 & & & & & & & & & & \\
\hline 15 & 93.6 & \begin{tabular}{|l|l|}
92.4 \\
\end{tabular} & 91.4 & 89.4 & 89.8 & 90.0 & 88.8 & 89.9 & 89.2 & $979 \mathrm{~b}$ & $96.4 \mathrm{~b}$ & 100 & & & & & & & & & \\
\hline 112 & 91.5 & \begin{tabular}{|l|l}
90.6 \\
\end{tabular} & 91.3 & $\begin{array}{l}90.9 \\
\end{array}$ & 91.0 & 89.6 & 88.7 & 89.5 & 89.9 & $94.9 \mathrm{~b}$ & $95.2 \mathrm{~b}$ & $95.7 \mathrm{~b}$ & 100 & & & & & & & & \\
\hline 74 & 92.0 & \begin{tabular}{|l|l|}
92.8 \\
\end{tabular} & 92.0 & 89.7 & 89.2 & 90.2 & 89.3 & 89.4 & 89.3 & 94.76 & $95.6 \mathrm{~b}$ & $95.2 \mathrm{~b}$ & $95.0 \mathrm{~b}$ & 100 & & & & & & & \\
\hline 77 & 90.3 & \begin{tabular}{|l|}
89.3 \\
\end{tabular} & 90.9 & \begin{tabular}{|l|l|}
94.6 \\
\end{tabular} & 95.3 & 92.7 & 92.4 & 91.5 & 92.7 & $95.8 \mathrm{~b}$ & $95.2 \mathrm{~b}$ & 94.0 & 93.7 & $93.3 \mathrm{~b}$ & 100 & & & & & & \\
\hline 78 & 91.2 & \begin{tabular}{|l|l|}
91.4 \\
\end{tabular} & \begin{tabular}{|l|l|}
91.6 \\
\end{tabular} & \begin{tabular}{|l|l}
93.0 \\
\end{tabular} & 93.0 & 91.6 & 90.9 & \begin{tabular}{|l}
90.6 \\
\end{tabular} & 92.0 & 95.36 & $94.9 \mathrm{~b}$ & 93.7 & $94.8 \mathrm{~b}$ & 93.1 & \begin{tabular}{|l|l|}
$95.4 \mathrm{~b}$ \\
\end{tabular} & 100 & & & & & \\
\hline 136 & 90.0 & \begin{tabular}{|l|}
90.0 \\
\end{tabular} & 89.7 & \begin{tabular}{|l|l|}
90.8 \\
\end{tabular} & 90.0 & 88.3 & 87.8 & 87.1 & 88.6 & \begin{tabular}{|l|}
91.1 \\
\end{tabular} & \begin{tabular}{|l|}
91.1 \\
\end{tabular} & 89.9 & 90.2 & 90.3 & \begin{tabular}{|l|l}
90.3 \\
\end{tabular} & 90.0 & 100 & & & & \\
\hline 161 & 89.7 & \begin{tabular}{|l|l}
88.8 \\
\end{tabular} & 89.2 & $\begin{array}{l}90.0 \\
\end{array}$ & 90.4 & 89.0 & 89.0 & \begin{tabular}{|l|l}
86.7 \\
\end{tabular} & 88.9 & \begin{tabular}{|l|}
91.5 \\
\end{tabular} & \begin{tabular}{|l|l}
90.7 \\
\end{tabular} & 89.5 & 90.6 & 89.1 & \begin{tabular}{|l|}
89.9 \\
\end{tabular} & 90.3 & $100 \mathrm{~s}$ & 100 & & & \\
\hline 103 & 87.2 & \begin{tabular}{|l|}
87.9 \\
\end{tabular} & \begin{tabular}{|l|l|}
90.6 \\
\end{tabular} & $\begin{array}{l}88.8 \\
\end{array}$ & 88.4 & 88.2 & 87.4 & 86.5 & 90.0 & \begin{tabular}{|l|}
87.8 \\
\end{tabular} & 88.1 & 88.5 & 87.6 & 88.1 & \begin{tabular}{|l|}
87.3 \\
\end{tabular} & 86.8 & 87.5 & 87.5 & 100 & & \\
\hline 10 & 88.3 & \begin{tabular}{|l|l|}
88.4 \\
\end{tabular} & 88.9 & \begin{tabular}{|l|}
89.1 \\
\end{tabular} & 89.4 & 88.1 & 89.9 & 88.5 & 89.3 & \begin{tabular}{|l|}
87.7 \\
\end{tabular} & 88.3 & 86.4 & 86.8 & 87.7 & \begin{tabular}{|l|l|}
88.5 \\
\end{tabular} & 87.8 & 87.5 & 87.0 & 86.4 & 100 & \\
\hline 12 & 88.8 & \begin{tabular}{|l}
87.8 \\
\end{tabular} & 88.4 & 88.6 & 89.1 & 87.7 & \begin{tabular}{|l|}
89.2 \\
\end{tabular} & 88.1 & 88.4 & \begin{tabular}{|l}
86.7 \\
\end{tabular} & $\begin{array}{l}87.0 \\
\end{array}$ & 86.1 & 85.6 & 86.9 & \begin{tabular}{|l|}
87.1 \\
\end{tabular} & 86.3 & 87.6 & 86.7 & 85.3 & $90.8 \mathrm{c}$ & 100 \\
\hline
\end{tabular}


(Marschall et al., 2009; Tissot et al., 2014). Nosocomial infections or healthcare associated infections in immunocompromised patients with cancer may be due to equipment and material used in the hospital or healthcare facility often become contaminated with bacterial strains that may be transferred to immunocompromised patients (Abdallah et al., 2008).Bacteremia is among the main causes of infections in cancer patients and had been correlated with decreased survival compared with cancer patients without bacteremia (Samonis et al., 2013). This is the first study in Basrah province to detect the geographical distribution of adult oncology patients with bacteremia and the bacterial etiology. The number of patients with bacteremia was 64 $(36.3 \%)$, which is within other reported values of 27 38\%. (Pereira et al., 2013; Al-Mulla et al.,2014). Although, all age groups were statistically insignificant among bacteremic and non bacteremic cancer patients (Table 3) suggesting all age groups of cancer patients are prone to bacterial infections, but the bacteremic episodes were significantly higher $59.25 \%$ in the age group 30-60 years which reflects the high incidence of cancer cases among this age group, the results are in agreement with Hussain (2015). Furthermore, 51\% of the patients involved in the episodes were males and $48 \%$ were female which fall within the reported range of $48-52 \%$ respectively (Kelly et al., 2010; Al-Mulla et al., 2014; Moghnieh et al., 2015). The bacteremic episodes among all leukemic patients was observed to be significantly higher $(64.06 \%)$ compared with lymphomas and solid tumors. This is in agreement with the results of Asturias et al.(2010); Al-Mulla et al. (2014); Moghnieh et al. (2015), indicating that patients with hematological malignancies, in particular, leukemic patients, are more prone to BSIs. Patients with hematologic malignancies may have normal or even high neutrophil accounts, but the risk is in infection as a result of defects in neutrophil function including a significant decrease in phagocytosis, reduction in bactericidal and fungicidal activity, reduction in production of superoxide anions and defects in granulocyte movement (Nesher and Rolston 2014) . On the other hand, the percentage of solid tumor was significantly higher among nonbacteremic cancer patients, because in such patients profound neutropenia is generally short lived and neutrophil function is usually normal (Nesher and Rolston 2014). This also may suggest that bacteremia may be involved in the occurrence of leukemia while solid tumor resulted from different causes other than bacteremia. The presence of neutropenia was statistically insignificant among bacteremic and non bacteremic cancer patients, while $71.87 \%$ of bacteremic episodes were neutropenic and $28.12 \%$ of episodes did not have a neutropenia at the time of diagnosis. This is in consistent with results from other groups who found BSI in neutropenic and nonneutropenic cancer patients (Gupta et al., 2010; Samonis et al., 2013; Al-Mulla et al., 2014; Bartholomew et al., 2015). Regarding that, neutropenia makes cancer patients at higher risk for serious infections and complications, since, the relationship between fever, neutropenia and bacteremia has been well known for more than 40 years. (Gaur et al., 2001; Asturias et al., 2010). Bacteremic episodes among healthcare center's cancer patients as well as among those who did not have a history of antibiotic intake were high and the difference was not statistically significant among bacteremic and non bacteremic cancer patients suggesting that the occurrence of bacteremia may have been an indirect outcome of the greater immunosuppression in these patients. Moghnieh et al. (2015) reported no statistical relationship between bacteremia and hospitalization in cancer patients. Similarly, there was a negative association between submission to surgery and the occurrence of bacteremia among cancer patients suggesting the former factor was not a risk factor.

Four genera and eleven species have been identified, the Gram-positive organisms were found to be the most common organisms with $63(98.43 \%)$. A similar trend has been documented in several reports including Ozkocaman et al. (2006) examined bacteremic isolates among hematologic malignancies patients throughout 2000-2005, 65.1\% of bacteremic episodes were caused by Gram-positive pathogens. Moreover, a study involving cancer patients with febrile neutropenia adduced $62.7 \%$ of patients with Gram-positive bacteremia (Feld, 2008). Kjellander et al. (2012) examined the trends in the epidemiology of bacteremia occurred during chemotherapy-induced neutropenia in hematologic malignancy patients receiving no antibiotic from 2002 to 2008, the proportion of Gram-positive isolates was $53.1 \%$. Gram-positive bacteremias were mostly due to Bacillus species. Bacillus licheniformis alone outnumbered other species and accounted $32.81 \%$ of bacteremic episodes followed by Bacillus cereus (29. $68 \%$ ) as Table (5). Several cases of Bacillus spp. bacteremia in cancer patients have been documented. Gaur et al. (2001) found twelve cases of Bacillus cereus septicemia in pediatric cancer patients. Ginsburg et al. (2003) reported a case of fatal $B$. cereus sepsis in a patient with newly diagnosed acute leukemia. In Ozkocaman et al. (2006) study, Bacillus bacteremias constituted $12(3.4 \%)$ of the bacteremic episodes occurred among hematologic malignancy patients including 7 Bacillus licheniformis, 3 Bacillus cereus and 2 Bacillus pumilus. Chou et al. (2013) identified a Bacillus cereus septicemia in a 15-yearold patient with B-cell acute lymphoblastic leukemia. In a study conducted by Kalantar et al. (2014) in 
patients with cancer, $20 \%$ of bacteremia episodes were due to Bacillus cereus. For aforesaid reasons, Bacillus spp. isolated from the blood culture of patients with malignancies and fever should not be viewed routinely as a contaminant, but assessed as a potential pathogen (Ozkocaman et al., 2006). However, coagulase-negative staphylococci (CoNS) comprised $6.24 \%$ of bacteremic episodes in cancer patients and caused by $S$. epidermidis and $S$. warneri. Coagulase negative staphylococci (CoNS) are isolated most often from cancer patients, especially, Staphylococcus epidermidis, S. haemolyticus and $S$. hominis, these pathogens are of low virulence and rarely cause life-threatening infections even in intensely neutropenic patients, the BSI are the most usual infections caused by CoNS (Nesher and Rolston 2014). Lysinibacillus spp. were also identified in the present study which is usually regarded as contaminants if isolated in the laboratory foremost due to their ubiquitous nature and lack of pathogenicity, despite this, they have been known to cause severe infections in humans, furthermore, bacteremia has been the most usual presentation of systemic infections due to these species (Wenzler et al., 2015). The largest case report of L. sphaericus bacteremia represented 12 cases over a 10 year period at a children's cancer hospital in Italy (Castagnola et al., 2001). Enterobacter cancerogenus was also isolated and it is one of the new species identified (Garazzino et al., 2005). Several cases reported E. cancerogenus associated with human infections (Rubinstien et al., 1993; Abbott and Janda 1997; Tena et al., 2015). To date, no confirmed cases of bacteremia associated with E. cancerogenus in cancer patients have been reported.

Three isolates of Bacillus licheniformis No. 15,17 and 48 ( $1 \%$ difference in $16 \mathrm{~S}$ rDNA sequence) from the blood of cancer patients were reported as new strains, because the accumulative results from a several studies suggested a range of about a $0.5 \%$ to $1 \%$ difference ( 99.5 to $99 \%$ similarity) is often utilized for classification (Abd Al-Abbas, 2012). These new strains may be resulted from a mutation occurred during their transmission from one environment to another.

According to its number, the diversity of Bacillus licheniformis was further illustrated in their RAPD patterns. The present study recognized four strains each two were identical and isolated from two different patients (Figure 4). Interestingly, the four patients were from various regions in the province and all had a similar history of healthcare exposure or a history of hospitalization, the presence of similar strains within different patients could be due to the localization of the patients in the same wards of the hospital or healthcare facility but at different times which may indicate particular problems in these areas. Furthermore, 14 patients had closely related strains of Bacillus licheniformis with 94.4-98.3\% similarity among them, these isolates might have evolved from the same origin (same strain), but, lost or acquired several nucleotides during the dissemination in the new environment. Furthermore, 2 patients had related strains of $90.8 \%$ similarity, since isolates that produced fingerprints with $\geq 80 \%$ similarity were considered as related (Hadi, 2015). However, with the exception of $100 \%$ for identical relatedness, there is no a precise percentage to detect the closely or related relationship among the organisms, because all these relatedness is depended on the number of organisms that using in the test.

\section{Conclusion}

The frequency of oncology patients with or without bacteremia was not equal among the regions of Basrah province. Bacteremial infections can consider as indicators for oncology treat especially leukemia, with interest by some clinical factors including age, healthcare exposure, non-antibiotic administration, neutropenia and fever. The pattern of bacteremia is tending towards Gram-positive organisms with a predominant of Bacillus licheniformis and Bacillus cereus. However, the isolation of Gr-ve Enterobacter cancerogenus from BSI of cancer patients is reported for the first time. Moreover, three new global bacterial strains from bacteremia were recorded. Finally, four cases (each two had the same strain of B. licheniformis) from different regions and another 16 cases from different patients had a closely related or related strains of $B$. licheniformis, these results confirm that they were either HCA or HA.

\section{Acknowledgement}

The authors are grateful to the laboratory of Cell and Biotechnology Researches Unit, and The Center of Oncology and Hematology/Al-Saddar Educational Hospital in Basrah province for sampling in this project.

\section{References}

1. Abbott, S. L. and Janda, J. M. (1997). "Enterobacter cancerogenus (Enterobacter taylorae) Infections Associated with Severe Trauma or Crush Injuries". Microbiology and Infectious Disease 359-361.

2. Abdallah, S. N. A., Al-dabbag, R. and Baqir, H. I. (2008). "Nosocomial Bacteremia in Leukopenic Patients with Leukemia in Baghdad Teaching Hospital" The Iraqi Postgraduate Medical Journal 7 (4): 327-31.

3. Abd Al-Abbas, M. J. (2012). "Antimicrobial Susceptibility of Enterococcus faecalis and a Novel Planomicrobium Isolate of Bacterimia." International Journal of Medicine and Medical Sciences 4 (2): 19-27.

4. Abd Al-Abbas, M. J. and Chemagh, A.A. (2014). "Molecular Genetic Study Confirming the Transmission of Nasopharyngeal Bacteria to Middle Ear in Patients with Chronic Supportive Otitis Media, Including New Global Strains in GenBank: MunaAla1, MunaAla2, IRQBAS5 and 
IRQBAS6". International Journal of Pharmaceutical Research and Bioscience 3 (2): 379-97.

5. Al-Mulla, N. A., Taj-Aldeen,S. J., El Shafie, S., Janahi, M. Al-Nasser, A. A. and Chandra, P. (2014). "Bacterial Bloodstream Infections and Antimicrobial Susceptibility Pattern in Pediatric Hematology/Oncology Patients after Anticancer Chemotherapy." Infection and Drug Resistance 7: 289-99.

6. Asturias, E. J., Corral, J. E. and Quezada, J. (2010). "Evaluation of Six Risk Factors for the Development of Bacteremia in Children with Cancer and Febrile Neutropenia." Current Oncology17 (2): 59-63.

7. Åttman, E., Aittoniemi, J., Sinisalo, M., Vuento, R., Lyytikäinen, O., Kärki, T., Syrjänen, J. and Huttunen, R. (2015). "Etiology, Clinical Course and Outcome of Healthcare-Associated Bloodstream Infections in Patients with Hematological Malignancies: A Retrospective Study of 350 Patients in a Finnish Tertiary Care Hospital." Leukemia \& Lymphoma 56 (12): 3370-77.

8. Japoni, A., Alborzi, A., Rasouli, M. and Pourabbas, B. (2004). "Modified DNA Extraction for Rapid PCR Detection of Methicillin-Resistant Staphylococci." Iranian Biomedical Journal 8 (3): 161-165.

9. Bartholomew, F., Aftandilian, C., Andrews, J., Gutierrez, K., Luna-Fineman, S. and Jeng, M. (2015). "Evaluation of Febrile, Nonneutropenic Pediatric Oncology Patients with Central Venous Catheters Who are Not Given Empiric Antibiotics." The Journal of Pediatrics 166 (1): 157-62.

10. Castagnola, E., Fioredda, F., Barretta, M., Pescetto, L., Garaventa, A., Lanino, E., Micalizzi, C., Giacchino, R. and Dini, G. (2001). "Bacillus Sphaericus Bacteraemia in Children with Cancer: Reports, C. and Literature Review." The Journal of Hospital Infection 48 (2): 142-45.

11. Chou, Y., Cheng, S., Hsieh, K., Wang, C., Chen, S. and Lo, W. (2013). "Bacillus Cereus Septicemia in a Patient with Acute Lymphoblastic Leukemia: A Case Report and Review of the Literature." Journal of Microbiology, Immunology and Infection 49 (3): 4-7.

12. CSO, (2014) "Environmental Statistics Report in Iraq for the year 2014" available at http://www.cosit.gov.iq.

13. El-Hamshary, O. I. M., Mohammed, H., Sheikh, A. and Khattab, A. A. (2012). "Molecular Characterization of Bacteria Isolated from the Kingdom of Saudi Arabia and Their Uses against Pathogenic Fungi Causing Dermatological Diseases." African Journal of Biotechnology 11 (89): 1551015.

14. El-mahallawy, H. A., Hassan, S. S., El-wakil, M. and Moneer, M. M. (2015). "Update on Healthcare-Associated Blood Stream Infections in Febrile Neutropenic Pediatric Oncology Patients" Journal of Cancer Therapy 6:504-10.

15. Essa, S. S., Habib, O. S., Al-Diab, J. M. A., Al-Imara, K. A. S. and Ajeel, N. A. H. (2007). "Cancer Mortality in Basrah." The Medical Journal of Basrah University 25: 55-60.

16. Fares, S., Lamchahab, M., Zerouali, K., Serhier, Z., Benchekroun, S. and Quessar A. (2013). "Surveillance of Healthcare Associated Infections in Hematology: Prospective Study about 237 Patients." Blood 122 (21): 1-9

17. Feld, R. (2008). "Bloodstream Infections in Cancer Patients with Febrile Neutropenia." International Journal of Antimicrobial Agents 32 : 30-33.

18. Garazzino, S., Aprato, A., Maiello, A., Masse, A., Biasibetti, A., De Rosa, F. G. and Perri, G. Di. (2005). "Osteomyelitis Caused by Enterobacter Cancerogenus Infection Following a Traumatic Injury: Case Report and Review of the Literature." Journal of Clinical Microbiology 43 (3): 1459-61.

19. Gaur, H., Patrick, C. C., McCullers, J., Flynn, P. M., Pearson, T., Razzouk, B. I., Thompson, S. J. and Shenep, J. L. (2001). "Bacillus Cereus Bacteremia and Meningitis in Immunocompromised Children." Clinical Infectious Diseases: 1456-62.

20. Ginsburg, A. S., Salazar, L. G., True, L. D. and Disis, M. L. (2003). "Fatal Bacillus Cereus Sepsis Following Resolving
Neutropenic Enterocolitis during the Treatment of Acute Leukemia." American Journal of Hematology 72 (3): 204-8.

21. Katherason, G. S., Naing, L., Jaalam, K., Musa, K. K. I., Abdullah, N. M. N., Aiyar, S., Bhojwani, K., Harussani, N., Abdul Rahman, A. and Ismail, A. (2010). "Prospective Surveillance of Nosocomial Device-Associated Bacteremia in Three Adult Intensive Units in Malaysia." Tropical Biomedicine 27 (2): 308-16.

22. Gupta, A., Singh, M., Singh, H., Kumar, L., Sharma, A., Bakhshi, S., Raina, V. and Thulkar, S. (2010). "Infections in Acute Myeloid Leukemia: An Analysis of 382 Febrile Episodes." Medical Oncology 27 (4): 1037-45.

23. Hadi, Z. J. (2015). "Prevalence of Plasmid-Mediated Quinolones Resistance Genes in Clinical Isolates of Klebsiella Pneumoniae in Najaf Hospitals" PhD. Thesis. Faculty of Medicine. University of Kufa. Iraq.

24. Hussain, R. A. (2015). "Cancer in Basrah: Extent, Validation of Registration and Patients Behavior". PhD Thesis, College of Medicine. University of Basrah. Iraq.

25. Kalantar, E., Aghabarari, M., Asgari, E., Assadi, M., Marashi, M. A., Hatami, S. and Shakib, A. (2014). "Survey of Enteric Pathogens Causing Bacteremia in Cancer Patients"International jouranl of Enteric Pathogens 2 (2):1-3.

26. Kelly M., Vivier, P., Panken, T. and Schwartz, C. (2010). "Bacteremia in Febrile Nonneutropenic Pediatric Oncology Patients Michael." Pediatric Blood Cancer 54: 83-87.

27. Kjellander, C., Björkholm, M., Cherif, H., Kalin, M. and Christian, G. G. (2012). "Hematological: Low All-Cause Mortality and Low Occurrence of Antimicrobial Resistance in Hematological Patients with Bacteremia Receiving No Antibacterial Prophylaxis: A Single-Center Study." European Journal of Haematology 88 (5): 422-30.

28. Lenz, R., Leal, J. R., Church, D. L., Gregson, D. B., Ross, T. and Laupland, K. B. (2012). "The Distinct Category of Healthcare Associated Bloodstream Infections." $B M C$ Infectious Diseases 12 (1): 85-91

29. Maiti, B., Shekar, M., Khushiramani, R., Karunasagar, I. and Karunasagar, I. (2009). "Evaluation of RAPD-PCR and Protein Profile Analysis to Differentiate Vibrio Harveyi Strains Prevalent along the Southwest Coast of India." Journal of Genetics 88 (3): 273-79.

30. Marschall, J., Fraser, V. J, Doherty, J. and Warren, D. K. (2009). "Between Community and Hospital: HealthcareAssociated Gram-Negative Bacteremia among Hospitalized Patients." Infection Control and Hospital Epidemiology: The Official Journal of the Society of Hospital Epidemiologists of America 30 (11): 1050-56.

31. Miyoshi, T., Iwatsuki, T. and Naganuma, T. (2005) "Phylogenetic Characterization of 16S rRNA Gene Clones from Deep-Groundwater Microorganisms That Pass through 0 . 2-Micrometer-Pore-Size Filters". Applied and Environmental Microbiology 71 (2): 1084-88.

32. Moghnieh, R., Estaitieh, N., Mugharbil, A., Jisr, T., Abdallah, D. I., Ziade, F., Sinno, L. and Ibrahim, A. (2015). "Third Generation Cephalosporin Resistant Enterobacteriaceae and Multidrug Resistant Gram-Negative Bacteria Causing Bacteremia in Febrile Neutropenia Adult Cancer Patients in Lebanon, Broad Spectrum Antibiotics Use as a Major Risk Factor, and Correlation W." Frontiers in Cellular and Infection Microbiology 5 (11): 1-9.

33. Montassier, E., Batard, E., Gastinne, T., Potel, G. and De La Cochetière, M. F. (2013). "Recent Changes in Bacteremia in Patients with Cancer: A Systematic Review of Epidemiology and Antibiotic Resistance." European Journal of Clinical Microbiology and Infectious Diseases 32 (7): 841-50.

34. Nesher, L. and Rolston, K. V. I. (2014). "The Current Spectrum of Infection in Cancer Patients with Chemotherapy Related Neutropenia". Infection 42:5-13.

35. Ozkocaman, V., Ozcelik, T., Ali, R., Ozkalemkas, F. and Ozkan, A. (2006). "Bacillus Spp. among Hospitalized Patients with Haematological Malignancies: Clinical 
Features, Epidemics and Outcomes.”. Journal of Hospital Infection. 1-8

36. Parikh, H. R., De, A. S. and Baveja, S. M. (2012). "Comparison of the Lysis Centrifugation Method with the Conventional Blood Culture Method in Cases of Sepsis in a Tertiary Care Hospital," Journal of Laboratory Physicians 4 (2): 2-6.

37. Pereira, Pires, C. A., Marra, A. R., Camargo, L. F. A., Pignatari, A. C. C., Sukiennik, T., Behar, P. R. P., Medeiros, E. A. S. (2013). "Nosocomial Bloodstream Infections in Brazilian Pediatric Patients: Microbiology, Epidemiology, and Clinical Features." PLOS ONE 8 (7): 8-13.

38. Rolston, K. V. I., Yadegarynia, D., Kontoyiannis, D. P., Raad, I. I. and Ho, D. H. (2006). "The Spectrum of GramPositive Bloodstream Infections in Patients with Hematologic Malignancies and the in Vitro Activity of Various Quinolones against Gram-Positive Bacteria Isolated from Cancer Patients." International Journal of Infectious Diseases: 10 (3): 223-30.

39. Ronimus, R. S., Parker, L. E., Morgan, H. W. and Mesophilic, B. (1997). "The Utilization of RAPD-PCR for Identifying Thermophilic and Mesophilic Bacillus Species" FEMS Microbiology Letters 147: 75-79.

40. Rubinstien, E. M., Klevjer-anderson, P., Smith, C. A., Drouin, M. T. and Patrerson, J. A. N. E. (1993). "New Opportunistic Pathogen: Report of Four Cases". Journal of Clinical Microbiology. 31 (2): 249-54.

41. Samonis, G., Vardakas, K. Z., Maraki, S., Tansarli, G. S., Dimopoulou, D., Kofteridis, D. P., Andrianaki, A. M. and Falagas, M. E. (2013). "A Prospective Study of Characteristics and Outcomes of Bacteremia in Patients with Solid Organ or Hematologic Malignancies." Supportive Care in Cancer 21 (9): 2521-26.
42. Tena, D., Lago, M. R., Sáez-nieto, J. A., Medina, M. J., Lara, N. and Oteo, J. (2015). "Surgical Site Infection Caused by Enterobacter cancerogenus A Case Report and Review of Literature". Infectious Diseases in Clinical Practice 23 (6): 289-91.

43. Tissot, F., Calandra, T., Prod'hom, G., Taffe, P., Zanetti, G., Greub, G. and Senn, L.. (2014). "Mandatory Infectious Diseases Consultation for MRSA Bacteremia Is Associated with Reduced Mortality." Journal of Infection 69 (3). 22634.

44. Towner, K. J., Levi, K., Vlassiadi, M. and Steering, A. (2008). "Genetic Diversity of Carbapenem-Resistant Isolates of Acinetobacter Baumannii in Europe." Clinical Microbiology and Infection 14 (2): 161-167.

45. Wenzler, E., Kamboj, K. and Balada-Llasat, J. M. (2015) "Severe Sepsis Secondary to Persistent Lysinibacillus sphaericus, Lysinibacillus fusiformis and Paenibacillus amylolyticus Bacteremia." International Journal of Infectious Diseases 35:93-95.

46. Wisplinghoff, H., Seifert, H., Wenzel, R. P. and Edmond, M. B. (2003). "Current Trends in the Epidemiology of Nosocomial Bloodstream Infections in Patients with Hematological Malignancies and Solid Neoplasms in Hospitals in the United States." Clinical Infectious Diseases 36 (9): 1103-10.

47. Woo, P. C. Y., Lau, S. K. P., Teng, J. L. L., Tse, H. and Yuen, K. (2008). "Then and Now: Use of 16S rDNA Gene Sequencing for Bacterial Identification and Discovery of Novel Bacteria in Clinical Microbiology Laboratories." European Society of Clinical Infectious Diseases 14 (10): 908-34. 